\title{
Identifying FDI Spillovers
}

\author{
Yi Lu, ${ }^{\text {a }}$ Zhigang Tao, ${ }^{\mathrm{b}}$ and Lianming $\mathrm{Zhu}^{\mathrm{c}}$ \\ ${ }^{\mathrm{a}}$ National University of Singapore, Singapore \\ ${ }^{\mathrm{b}}$ University of Hong Kong, Hong Kong \\ ${ }^{\mathrm{c}}$ Kyoto University, Japan
}

This Version: November 2015

\begin{abstract}
This paper improves on the strategy used in the literature to identify the spillover effect of horizontal FDI by taking advantage of the plausibly exogenous relaxation of FDI regulations upon China's WTO accession at the end of 2001. In addition, we evaluate the two prevailing explanations (the agglomeration effect versus the competition effect, and the absorptive capacity of domestic firms) for FDI spillovers. Finally, we use an array of performance measures, including TFP, exporting performance, wages, R\&D investment, and firm survival, to offer a fuller picture of the specific areas where the presence of foreign multinationals may benefit or harm domestic firms.
\end{abstract}

Keywords: FDI Spillovers; Difference-in-Differences; Agglomeration Effect; Competition Effect; Absorptive Capacity; China

JEL Classification: F2, O3, R1 


\section{Introduction}

Over the past few decades, developing countries around the world have removed restrictions on foreign direct investment (FDI) and even adopted policies to attract FDI, in the belief that domestic firms can benefit from the presence of FDI. However, empirical studies using firm-level panel data from developing countries have often failed to find evidence that domestic firms benefit from the presence of FDI in the same industry (referred to as horizontal FDI), and some have even found that FDI has a negative effect on domestic firms. ${ }^{1}$ Apparently, the decision by foreign multinationals to enter developing countries and particular industries is an endogenous one, which partially explains why it is difficult to identify the FDI spillovers on domestic firms. The lack of consensus in the academic literature on the effect of FDI on domestic firms (generally referred to as the FDI spillover effect) prompts us to reexamine this research question.

We improve on the identification strategy used in the literature (namely, the inclusion of industry or firm fixed effects) by taking advantage of the plausibly exogenous relaxation of FDI regulations upon China's WTO accession at the end of 2001. Specifically, upon its WTO accession, China opened up some industries (i.e., 113 out of the 425 4-digit manufacturing industries) for FDI, and these industries have indeed experienced a surge of FDI inflows since 2002. Using this shock as an instrument for the presence of FDI, we are able to compare firm performance in our treatment group (i.e., industries that encouraged FDI entries) with performance in our control group (i.e., industries that did not have any change in FDI regulations) before and after China's WTO accession at the end of 2001. Section 2 provides the details of China's FDI regulations and our empirical identification strategy. Our regression analyses and identification checks, provided in Section 3, show that horizontal FDI has a negative spillover effect on the performance of China's domestic firms.

In addition, in Section 4, we examine the strength of two explanations proposed in the literature for understanding the negative (aggregate) spillover effect of FDI on domestic firms. Aitken and Harrison (1999) argue that although domestic firms may enjoy a positive agglomeration effect from the presence of foreign multinationals

\footnotetext{
${ }^{1}$ Studies reporting the negative effects of horizontal FDI on domestic firms in developing countries include, for example, Haddad and Harrison (1993) for Morocco; Aitken and Harrison (1999) for Venezuela; Djankov and Hoekman (2000) for the Czech Republic; Konings (2001) for Bulgaria, Romania, and Poland; and Hu and Jefferson (2002) for China. However, most studies using data from developed countries report that FDI has a positive effect on domestic firms, e.g., Haskel, Pereira, and Slaughter (2007) and Keller and Yeaple (2009). See Görg and Strobl (2001), and Görg and Greenaway (2004) for recent surveys of this literature.
} 
through channels such as knowledge spillovers, input sharing, and labor pooling, ${ }^{2}$ they may lose market share to the more productive foreign multinationals, thereby suffering from the negative competition effect. In this study, we carefully disentangle these two opposite effects by distinguishing different types of FDI along various dimensions, such as FDI source countries (developed vs. developing countries), ${ }^{3}$ linkages (horizontal FDI vs. vertical FDI for short, namely, FDI in upstream or downstream industries), ${ }^{4}$ location of investment (within vs. outside of city) ${ }^{5}$ and the time horizon of the FDI spillover effect (static vs. dynamic). ${ }^{6}$ Consistently, we find that the negative spillover effect of horizontal FDI is stronger in scenarios where the competition effect is more pronounced, but that it is either smaller in magnitude, albeit negative, or even positive in cases where the agglomeration effect is more prominent; these findings lend support to the argument proposed by Aitken and Harrison (1999).

It has also been hypothesized in the literature that the FDI spillover effect on domestic firms hinges on their absorptive capacity. Using a panel dataset of Indonesian manufacturing firms for the 1988 to 1996 period, Blalock and Gertler (2009) find that firms with more R\&D investment benefit more from the presence of foreign multinationals. Following this line of the research, ${ }^{7}$ we investigate whether the negative FDI spillover effect on domestic firms can be explained by the differences of the domestic firms in their R\&D investment and ownership structure (state ownership vs. private ownership); we find weak support for the latter but not the former, suggesting that absorptive capacity plays a limited role in explaining whether domestic firms suffer from the presence of foreign multinationals in the same industry.

Finally, in addition to using the TFP (the most widely used performance indicator in the literature) to investigate the effect of FDI on domestic firms, we also examine, in Section 5, other performance measures used in the literature, specifically,

\footnotetext{
${ }^{2}$ See Blomström and Kokko (1998) for a discussion of these potential channels. Görg and Strobl (2007) and Balsvik (2011) provide evidence for spillovers through labor mobility.

${ }^{3}$ For recent studies on the origin of FDI, see Javorcik and Spatareanu (2011).

${ }^{4}$ For recent studies on horizontal vs. vertical FDI, see Javorcik (2004), Bwalya (2006), Kugler (2006), Blalock and Gertler (2008), Liu (2008), Lin, Liu, and Zhang (2009), Barrios, Görg, and Strobl (2011), Du, Harrison, and Jefferson (2012), Damijan, Rojec, Majcen, and Knell (2013), and Gorodnichenko, Svejnar, and Terrell (2014).

${ }^{5}$ For recent studies on the regional dimension of the effects of FDI, see Sjöholm (1999), Bwalya (2006), Halpern and Muraközy (2007), and Xu and Sheng (2012).

${ }^{6}$ For studies on the dynamic effect of FDI, see Liu (2008), Kosová (2010), and Merlevede, Schoors, and Spatareanu (2014).

${ }^{7}$ See, for example, Kokko (1994), Girma (2005a), Girma (2005b), and Lin, Liu, and Zhang (2009).
} 
exporting performance (probability of exporting and export intensity), ${ }^{8}$ wage rate, ${ }^{9}$ R\&D investment, ${ }^{10}$ and firm survival. ${ }^{11}$ We find that the presence of foreign multinationals has no significant effect on the exporting performance or R\&D investment of domestic firms in the same industries, leads to significant increases in the wage rate paid by domestic firms in the same industry, and decreases the exit probability of domestic firms in the same industry. Combined with the negative effect of FDI on the TFP of domestic firms, these results confirm that there is limited evidence that domestic firms benefit from the presence of foreign multinationals; this casts doubt on the policy orientations of many developing countries.

\section{Estimation Strategy}

\subsection{Regulations of FDI in China}

Before 1978, China was a closed economy under rigid central planning, and there was an almost complete absence of foreign-invested enterprises (FIEs) in the country. However, the situation changed dramatically in December 1978, when the then leader of China, Deng Xiaoping, initiated an open door policy to promote foreign trade and investment. A "Law on Sino-Foreign Equity Joint Ventures" was passed in July 1979 to attract foreign direct investment, and from the 1980s to the early 1990s, a series of laws on FDI and implementation measures were further introduced and revised. ${ }^{12}$ Specifically, both the central and local governments of China granted preferential policies on taxes, land usage, and other matters, often in the form of policies for special economic zones, to FIEs, which were expected to bring advanced technologies and management know-how to China and to promote China's integration into the world economy. As a result of these laws and implementation measures, China experienced a rapid growth in FDI inflows from 1979 to 1991 (Figure 1). After Deng

\footnotetext{
${ }^{8}$ For recent studies on the export effect of FDI, see Aitken, Hanson, and Harrison (1997), Barrios, Görg, and Strobl (2003), Greenaway, Sousa, and Wakelin (2004), and Banga (2006).

${ }^{9}$ For recent studies on the wage effect of FDI, see Aitken, Harrison, and Lipsey (1996) and Poole (2013).

${ }^{10}$ For a recent study on the R\&D effect of FDI, see Cheung and Lin (2004).

${ }^{11}$ For recent studies on the firm survival effect of FDI, see De Backer and Sleuwaegen (2003), Görg and Strobl (2003), and Kosová (2010).

${ }^{12}$ In September 1983, the "Regulations for the Implementation of the Law on Sino-Foreign Equity Joint Ventures" was issued by the State Council of China; it was revised in January 1986, December 1987, and April 1990. In April 1986, the "Law on Foreign Capital Enterprises" was enacted, and in October 1986, "Policies on Encouragement of Foreign Investment" was issued by the State Council of China.
} 
Xiaoping took a tour of Southern China in the spring of 1992 to revive a slowing economy, the FDI inflows to China grew even faster, reaching US\$27.52 billion in 1993.

\section{[Insert Figure 1 here]}

Despite the open-door policy and the removal of barriers to inward FDI from the late 1970s to the early 1990s, FIEs operating in China still faced significant obstacles. For example, FIEs had to meet local content requirements in manufacturing and exporting products, and were required to transfer advanced technologies and management know-how to local partners.

Most significantly, there were policies designating which industries were permitted to accept foreign direct investment. In June 1995, the central government of China promulgated the "Catalogue for the Guidance of Foreign Investment Industries" (henceforth, the Catalogue), which, together with the modifications made in 1997, became the government guidelines for regulating the inflows of FDI. Specifically, the Catalogue classified products into four categories: (i) FDI was supported, (ii) FDI was permitted, (iii) FDI was restricted, and finally, (iv) FDI was prohibited. After China's entry into the World Trade Organization (WTO) in November 2001, its central government substantially revised the Catalogue in March 2002, and made minor revisions in November 2004. In this study, we use the plausibly exogenous relaxation of FDI regulations upon China's WTO accession at the end of 2001 to identify the spillover effect of horizontal FDI on domestic firms. ${ }^{13}$

\subsection{Data}

Panel data on industrial firms. The main data used in this study are from the Annual Survey of Industrial Firms (ASIF), conducted by the National Bureau of Statistics of China for the 1998-2007 period. ${ }^{14}$ These surveys cover all of the state-owned enterprises (SOEs) and those non-SOEs with annual sales over 5 million Chinese yuan (about US\$827,000). The number of firms covered in the surveys varies from approximately 162,000 to approximately 270,000 . The dataset has more than 100 variables, including the basic information for each surveyed firm, such as its identification number, location code, industry affiliation, and ownership structure (including ownership by foreigners and the state, which can be used to calculate the foreign equity share and the state share), and the financial and operational information extracted from

\footnotetext{
${ }^{13}$ The National Development and Reform Commission and the Ministry of Commerce jointly issued the fifth and sixth revised versions of the Catalogue in October 2007 and December 2011.

${ }^{14}$ These data have been widely used by economic researchers in recent years, e.g., Lu, Lu, and Tao (2010), Brandt, Van Biesebroeck, and Zhang (2012), and Lu and Yu (2015).
} 
accounting statements, such as sales, employment, materials, fixed assets, and total wage bill.

For our study, we need precise industry information about our sample firms. In 2003, a new classification system for industry codes (GB/T 4754-2002) was adopted in China to replace the old classification system (GB/T 4754-1994) that had been used from 1995 to 2002 . To achieve consistency in the industry codes over our entire sample period (1998-2007), we use the concordance table constructed by Brandt, Van Biesebroeck, and Zhang (2012). ${ }^{15}$

Table 1 shows the distribution of foreign equity share (measured by outputweighted average of foreign equity share across all of the firms in an industry) across the 2-digit industries over the entire sample period (1998-2007), the pre-WTO period (1998-2001), and the post-WTO period (2002-2007). There are substantial variations in the extent of FDI across these industries in China, with the average foreign equity share ranging from $1.4 \%$ to $55.6 \%$. The Electronic and Telecommunications Equipment industry had the highest percentage of foreign direct investment $(55.6 \%)$ in the 1998-2007 period, followed by the Garments \& Other Fiber Products industry (42.6\%), and the Furniture Manufacturing industry (41.8\%). The industries with the lowest percentage of foreign direct investment were Tobacco Processing (1.4\%), Smelting and Pressing of Nonferrous Metals (6.4\%) and Smelting and Pressing of Ferrous Metals (6.7\%), all of which were monopolized and resource-intensive.

\section{[Insert Table 1 here]}

From the pre-WTO period to the post-WTO period, most of the industries experienced increases in the extent of foreign direct investment. Specifically, the Special Purpose Equipment industry witnessed the fastest growth rate in FDI (68.60\%), followed by Petroleum Processing \& Coking (41.94\%), and then the Raw Chemical Materials \& Chemical Products (33.73\%). However, some industries experienced decreases in foreign equity share, specifically, Tobacco Processing (declined by $38.89 \%$ ), and Timber Processing, Bamboo, Cane, Palm Fiber \& Straw Products (declined by

\footnotetext{
${ }^{15}$ One potential problem with the ASIF data is that, for firms with multiple plants located in regions other than their domiciles, the information about the satellite plants might be aggregated to that of the domicle-based plants. According to Article 14 of the Company Law of the People's Republic of China, however, for a company to set up a plant in a region other than its domicile, "it shall file a registration application with the company registration authority, and obtain the business license." For example, Beijing Huiyuan Beverage and Food Group Co., Ltd. has six plants, located in Jizhong (Hebei Province), Youyu (Shanxi Province), Luzhong (Shandong Province), Qiqihar (Heilongjiang Province), Chengdu (Sichuan Province), and Yanbian (Jilin Province). Our data set accordingly counts them as six different observations belonging to six different regions. Thus a firm in our data is essentially a plant.
} 
$13.66 \%)$.

Data on China's FDI regulations. To obtain information about changes in FDI regulations upon China's accession to the WTO, we compare the 1997 and 2002 versions of the Catalogue for the Guidance of Foreign Investment Industries. We focus on the 2002 version rather than the 2004/2007/2011 versions for three reasons. First, the revision to China's FDI regulations contained in the 2002 version of the Catalogue was substantial and in strict accordance with the commitments made by China's central government in its negotiations with the existing member countries of the WTO before its WTO accession. Second, there were very few changes in the 2004 revision of the Catalogue. Finally, the 2007 and 2011 modifications were not applicable to our sample period, which is from 1998 to 2007.

In the Catalogue, products were classified into four categories: (i) products where foreign direct investment was supported (the supported category), (ii) products (not listed in the Catalogue) where foreign direct investment was permitted (the permitted category), (iii) products where foreign direct investment was restricted (the restricted category), and finally, (iv) products where foreign direct investment was prohibited (the prohibited category).

Next, by comparing the 1997 and 2002 versions of the Catalogue, we can identify, for each product in the Catalogue, whether there was a change in the FDI regulations upon China's accession to the WTO. We then assign each product to one of three possible outcomes:

- FDI became more welcome (henceforth, such products are referred to as (FDI) encouraged products). For example, "dairy products" was listed in the supported category in the 2002 Catalogue, but listed in the permitted category in the 1997 Catalogue. We thus designate "dairy products" as (FDI) encouraged products.

- FDI became less welcome (henceforth, such products are referred to as (FDI) discouraged products). For example, "ethylene propylene rubber" was listed in the supported category in the 1997 Catalogue, but listed in the permitted category in the 2002 Catalogue. We thus designate "ethylene propylene rubber" as (FDI) discouraged products.

- No change in FDI regulations between 1997 and 2002. For example, "Casting and forging roughcasts for automobiles and motorcycles" was listed in the supported category in both the 1997 and 2002 Catalogues. We designate such products as no-change products. 
Table A1 lists a matrix of all of the possible changes in product categories (supported, restricted, prohibited, and permitted) between 1997 and 2002 with the corresponding classifications in the changes in FDI regulations (encouraged, discouraged, or no change).

Finally, we aggregate the changes in FDI regulations from the Catalogue product level to the ASIF industry level. As the product classifications used by the Catalogue are different from the industry classifications used in the ASIF data, we convert the product classifications of the Catalogue for the Guidance of Foreign Investment Industries into the 4-digit Chinese Industry Classification (CIC) of 2003 using the Industrial Product Catalogue from the National Bureau of Statistics of China. ${ }^{16}$ As the Chinese industry classification was revised in 2003, we use a concordance table from Brandt, Van Biesebroeck, and Zhang (2012) to create a harmonized Chinese Industry Classification that is consistent for the entire 1998-2007 period. As the product classifications of the Catalogue are generally more disaggregated than the 4-digit Chinese Industry Classifications of the ASIF, it is possible that two or more products from the Catalogue are sorted into the same 4-digit CIC industry of the ASIF. The aggregation process leads to four possible scenarios:

1. (FDI) Encouraged Industries: For all of the possible Catalogue products in a 4-digit CIC industry, there was either an improvement in FDI regulations or no change in FDI regulations. For example, four sub-categories under "Synthetic Fiber Monomer (Polymerization)" (CIC code: 2653) experienced improvements in FDI regulations (listed in the restricted category in the 1997 Catalogue, but the supported category in the 2002 Catalogue): "Pure Terephthalic Acid (PTA)" (CIC sub-code: 26530101), "Acrylonitrile" (26530103), "Caprolactam" (26530104), and "Nylon 66 Salt" (26530299); and there was no change in FDI regulations for the other sub-categories. We thus designate "synthetic fiber monomer (polymerization)" as an (FDI) encouraged industry.

2. (FDI) Discouraged Industries: For all of the possible Catalogue products in a 4-digit CIC industry, there was either a deterioration in FDI regulations or no change in FDI regulations. For example, one sub-category in "Food Additives" (CIC code: 1494) experienced a deterioration in FDI regulations (listed in the permitted category in the 1997 Catalogue but listed in the restricted category in the 2002 Catalogue): "Synthetic Sweeteners" (CIC sub-code: 14940103); and there were no changes in FDI regulations for the other sub-categories. We thus designate "Food Additives" as an (FDI) discouraged industry.

\footnotetext{
${ }^{16}$ The Industrial Product Catalogue lists each CIC 4-digit industry and its sub-categories at the 8-digit disaggregated product level.
} 
3. No-Change Industries: There was no change in FDI regulations for any of the possible Catalogue products under a 4-digit CIC industry. For example, in "Edible Vegetable Oil" (CIC code: 1331), all of the sub-categories were permitted in both the 1997 Catalogue and the 2002 Catalogue. We thus designate "Edible Vegetable Oil" as a no-change industry.

4. Mixed Industries: Some of the possible Catalogue products in a 4-digit CIC industry experienced an improvement in FDI regulations, but some had worsening FDI regulations. For example, under "Crude Chemical Medicine" (CIC code: 2710), the FDI regulations for one sub-category ("Vitamin B6" (CIC sub-code: 27100404)) improved (listed in the restricted category in the 1997 Catalogue, but the permitted category in the 2002 Catalogue), but the FDI regulations for one sub-category ("Vitamin E" (CIC sub-code: 27100408)) deteriorated (listed in the permitted category in the 1997 Catalogue, but in the restricted category in the 2002 Catalogue). We thus designate "Crude Chemical Medicine" as a mixed industry.

Among the 425 4-digit CIC industries, 113 are (FDI) encouraged industries (which is the treatment group in our regression analysis), 300 are no-change industries (which serves as the control group in our regression analysis), 7 are (FDI) discouraged industries and 5 industries are mixed industries; the latter two groups are excluded from the analysis. ${ }^{17}$

\subsection{Estimation Specification}

The benchmark model used in the literature to investigate the spillover effect of FDI on firm performance (e.g., Aitken and Harrison, 1999) is

$$
y_{f i t}=\alpha_{f}+\gamma_{t}+\delta F D I_{-} \text {Sector }_{i t}+\mathbf{X}_{f i t}^{\prime} \boldsymbol{\lambda}+\varepsilon_{f i t},
$$

where $f, i$, and $t$ denote the firm, 4-digit industry, and year, respectively; $y_{\text {fit }}$ measures the performance (e.g., total factor productivity) of firm $f$ of industry $i$ in year $t$; $\alpha_{f}$ and $\gamma_{t}$ are firm and year fixed effects, respectively; $\mathbf{X}_{f i t}$ is a vector of time-varying firm and industry characteristics used to isolate the effect of FDI spillover effect; and $\varepsilon_{f i t}$ is the error term. Following Bertrand, Duflo, and Mullainathan (2004), we address the potential serial correlation and heteroskedasticity issues by calculating the standard errors clustered at the industry level.

\footnotetext{
${ }^{17}$ The results (available upon request) remain robust when we include the discouraged industries in the analysis.
} 
FDI_Sector ${ }_{i t}$ is our regressor of interest, capturing the extent of FDI in industry $i$ and year $t$; and it is defined as

$$
F D I_{-} \text {Sector }_{i t}=\frac{\sum_{f \in \Omega_{i t}} F D I_{-} \text {Firm }_{f i t} \times \text { Output }_{f i t}}{\sum_{f \in \Omega_{i t}} \text { Output }_{f i t}},
$$

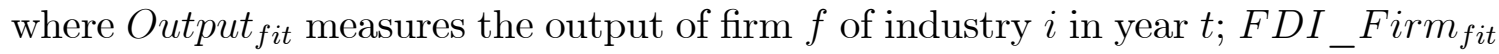
measures the foreign equity share of firm $f$ of industry $i$ in year $t$; and $\Omega_{i t}$ is the set of firms in industry $i$ in year $t$.

As our study concerns the spillover effect of FDI on domestic firms, we exclude from our regression sample all foreign firms (i.e., any firm with more than 25 percent of its equities owned by foreign investors, as such firms are entitled to preferential corporate tax rates offered for FIEs according to the Chinese law). The results obtained using the full sample but controlling for foreign equity share, as is common in the literature, are qualitatively the same and available upon request. The summary statistics of our key variables are presented in Table 2.

\section{[Insert Table 2 here]}

A crucial assumption for obtaining an unbiased estimate of $\delta$ in Equation (1) is that, conditional on all of the control variables, the regressor of interest is uncorrelated with the error term. It is reasonable to doubt that this identifying assumption holds in our setting. For example, there could be more FDI inflows to China's comparatively disadvantageous industries, where domestic firms already have lower productivity levels; this would bias towards the negative effects of FDI on domestic firms.

To deal with the identification problem, we use variations across industries in the changes in FDI regulations upon China's WTO accession as an instrument for FDI_Sector $i t$ and to identify the FDI spillover effect on domestic firms. Specifically, we compare firm performance in our treatment group (i.e., the encouraged industries) with firm performance in our control group (i.e., the no-change industries) before and after China's WTO accession at the end of 2001. The first-stage of our instrumental variable estimation is

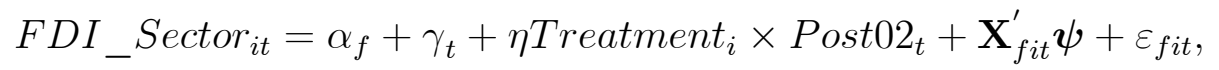

where Treatment $_{i}$ indicates whether industry $i$ belongs to the treatment group; and Post $02_{t}$ is a dummy indicating the post-WTO period, i.e., Post $02_{t}=1$ if $t>2002$, 
$3 / 4$ if $t=2002$, and 0 if $t<2002 .^{18}$

\subsection{Identifying Assumption and Checks}

Our instrument is only valid under the following conditions: 1) the share of FDI increased more in the encouraged industries than in the no-change industries upon China's accession to the WTO (or the relevance condition); and 2) variations across industries in the changes in FDI regulations upon China's WTO accession do not affect our outcomes through channels other than the share of FDI (or the exclusion restriction condition). Although the relevance condition can be confirmed by the significance of $\eta$ in equation (2), the exclusion restriction requires further discussion.

One primary threat to our identification is the comparability of our treatment and control groups. For example, the selection of which industries to open up to FDI upon the WTO accession was not random; hence, the encouraged industries and the no-change industries could have been experiencing different trends before the WTO accession and these differences might have generated differential trends in our outcomes across industries in the post-WTO period. To alleviate this identification concern, we first control for time-varying firm characteristics to balance firms in different industries. Specifically, we include, in $\mathbf{X}_{\text {fit }}$, firm output, its capital-labor ratio, a dummy variable indicating if a firm is an exporter, and a dummy variable indicating whether a firm is a state-owned enterprise (SOE). Then, following Gentzkow (2006), we first carefully characterize the potential determinants $\mathbf{Z}_{i 1998}$ of the changes in FDI regulations upon the WTO accession. As shown in Appendix A, four determinants are identified at the 4-digit industry level: new product intensity, export intensity, number of firms, and average age of firms. We then add interactions between $\gamma_{t}$ and $\mathbf{Z}_{i 1998}$ in $\mathbf{X}_{f i t}$ to control flexibly for post-WTO differences in the time path of the outcomes that are caused by the endogenous selection of industries for changes in FDI regulations.

A second potential problem is that other on-going policy reforms at the time of China's WTO accession might affect our outcomes through channels other than the share of FDI, leading to biased estimates of the spillover effect of FDI on domestic firms. One important policy reform in the early 2000s was the restructuring and privatization of SOEs. To control for the possibility that the extent of SOE restructuring and privatization differed across industries and affected our outcomes, we add the interaction between year dummies and industry SOE share in 2001 into $\mathbf{X}_{f i t}$. Furthermore, at the same time as China's WTO accession, there were substantial

\footnotetext{
${ }^{18}$ Post $02_{t}$ is $3 / 4$ for 2002 as the Catalogue 2002 was implemented on April 1, 2002. The results (available upon request) remain robust when Post $02_{t}$ equals 1 for 2002.
} 
tariff reductions by China and its trading partners, which affected the use of imported inputs and access to export markets. To condition out the tariff reduction effects, we include the interactions between the year dummies and various tariffs (specifically, China's output and input tariffs, and its export tariffs) in 2001 in $\mathbf{X}_{\text {fit }} .{ }^{19}$

A third potential concern is China's unique trading regime, namely, processing trading, which allows some firms to import intermediate inputs duty-free if they export all of their outputs. If the extent of processing traders changed discontinuously upon China's WTO accession and across industries, our estimates of the spillover effect of FDI may simply reflect the changes in this trading regime. To address this estimation concern, we first match the ASIF data to China's Customs data to identify processing traders, and then exclude these firms from the regression sample. ${ }^{20}$

Finally, we formalize the identification issues and carry out a placebo test. We decompose the error term into two parts: $\varepsilon_{f i t}=\beta \omega_{f i t}+\tilde{\varepsilon}_{f i t}$, such that

$$
\begin{aligned}
\operatorname{cov}\left(\text { Treatment }_{i} \times \text { Post }_{0} 2_{t}, \omega_{f i t} \mid \mathbf{W}_{\text {fit }}\right) & \neq 0, \\
\text { and } \operatorname{cov}\left(\text { Treatment }_{i} \times{\text { Post } 02_{t},}_{\tilde{\varepsilon}_{f i t}} \mid \mathbf{W}_{f i t}\right) & =0,
\end{aligned}
$$

where $\mathbf{W}_{\text {fit }}$ summarizes all of the controls in the regressions. In other words, all of the identification issues come from the omitted variable $\omega_{\text {fit }}$. Hence, our estimator $\hat{\delta}$ is

$$
\hat{\delta}=\delta+\beta \gamma,
$$

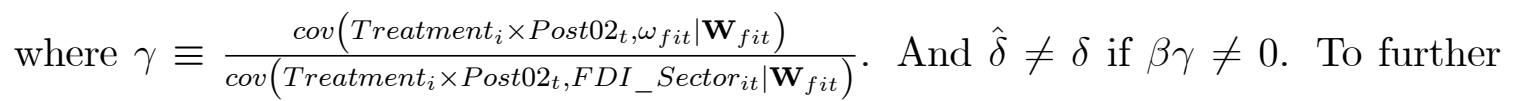
check whether our results are biased due to the omitted variable $\omega_{f i t}$, we conduct a placebo test by randomly generating the industry and time variations in the changes in FDI regulations. Specifically, we first randomly select 113 industries from the total 413 industries in the regression sample and assign them to the category of (FDI)

\footnotetext{
${ }^{19}$ The tariff data for HS-6 products are obtained from the World Integrated Trade Solution (WITS). By mapping HS-6 products to ASIF 4-digit industries through the concordance table from the National Bureau of Statistics of China, we can calculate simple average output tariff at the industry level. The input tariff is constructed as a weighted average of the output tariff, using as the weight share of the inputs in the output value from the 2002 China's Input-Output Table. The export tariff is measured as a weighted average of the destination country's tariffs on China's imports, using China's imports by each destination country as the weight.

${ }^{20}$ The ASIF dataset and the Customs dataset use different coding systems of firm identification. To identify processing traders in the ASIF data, we gather as much information as possible from the firm's name, location code, the name of the legal person, phone number, and so on to find a match in the Customs dataset, which has information about the types of exporters (including process traders).
} 
encouraged industries; then, we randomly choose a year from 1999-2006 (to make sure we have at least one year before the treatment and one year after the treatment for our DID analysis) as the year of the WTO accession; finally, we construct a false instrumental variable from these two randomizations, i.e., Treatment $t_{i}^{\text {false }} \times$ Post $_{t}^{\text {false }}$. The randomization ensures that Treatment ${ }_{i}^{\text {false }} \times$ Post $_{t}^{\text {false }}$ should have no effect on FDI inflows (i.e., $\eta^{\text {false }}=0$ ) and hence the regression of our outcome directly on Treatment $t_{i}^{\text {false }} \times$ Post $_{t}^{\text {false }}$ should produce zero effect; otherwise, it indicates the existence of the omitted variable $\omega_{\text {fit }} .{ }^{21}$ We conduct this random data generating process 500 times to avoid contamination by any rare events and to improve the power of the test.

\section{The Effect of FDI on Firm Productivity}

\subsection{Graphical Results}

We start with total factor productivity (TFP) as a measure of firm performance for our investigation, as it is the most widely used indicator in the literature. Specifically, we use the control function approach developed by Ackerberg, Caves, and Frazer (2015) to estimate the production function for each of the 29 two-digit industries, and then calculate the TFP for each firm and each year. The details of the production function estimation are provided in Appendix B.

Figure 2 displays a set of estimated coefficients from the regression of TFP on Treatment $t_{i} \times \gamma_{t}$ along with all of the controls in equation (1). The treatment and control groups were balanced in TFP in the pre-WTO period, indicating a good comparability between our treatment and control groups conditional on our selected controls. However, in the post-WTO period, the treatment group experienced a gradual and persistent decline in TFP compared with the control group, indicating that the relaxation of FDI regulations had a negative effect on firm productivity.

[Insert Figure 2 here]

\subsection{Regression Results}

Main results. The instrumental variable estimation results are reported in Table 3, with first stage estimates in panel $\mathrm{A}$ and second stage ones in panel B. In addition to firm and year fixed effects, we stepwisely include interactions between year

\footnotetext{
${ }^{21}$ Note that we cannot perform an instrumental variable estimation for this placebo test, as the instrument does not have the predictive power in the first stage.
} 
dummies and determinants of changes in FDI regulations and tariff reductions, interactions between year dummies and SOE share, and time-varying firm characteristics in columns 1-3. The inclusion of these additional controls allows us to isolate the effect of FDI spillovers from other confounding factors such as the endogenous selection of industries for changes in FDI regulations upon the WTO accession and other on-going policy reforms (SOE reform and tariff reduction) occurring at around the same period.

\section{[Insert Table 3 here]}

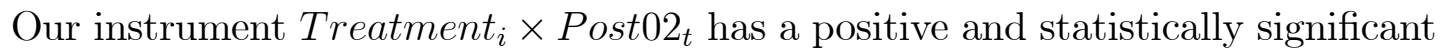
effect on FDI_Sector ${ }_{i t}$, confirming the argument that the relaxation of FDI regulations triggered inflows of FDI in the post-WTO period and hence the relevance of the instrument.

With respect to our central research focus, we find that, after being instrumented, FDI_Sector ${ }_{i t}$ consistently casts a negative and statistically significant effect on firm productivity. These results further confirm the findings in the literature (e.g., Aitken and Harrison, 1999; Konings, 2001) that the presence of FDI in the same industry hurts the productivity levels of domestic firms.

Robustness checks. We provide two robustness checks on the above results. First, in column 4 of Table 3, we exclude processing traders from our sample to alleviate the concern that our findings may be driven by changes in the trading regime upon China's accession to the WTO. Clearly, our estimates barely change in terms of both statistical significance and magnitude, suggesting that a possible change in the trading regime is not the main driver of our findings.

Second, as discussed in Section 2.4, we conduct a placebo test by randomly assigning the timing and the degree of changes in FDI regulations to industries. Figure 3 shows the distribution of the estimates from the 500 randomized assignments. We find that the distribution of these estimates is centered around zero (mean value of 0.0004), with a standard deviation of 0.0179. In addition, our true estimate (i.e., -0.048) lies beyond the 95 percentile of the 500 estimates. Combined, these observations suggest that the negative and significant effect of FDI on the productivity of domestic firms in the same industry is unlikely to be driven by unobserved factors.

Economic magnitude. To calculate the magnitude of the effect, we rely on the estimate in column 3 of Table 3 . We find that if the output-weighted share of FDI in an industry increases by $10 \%$, the average logarithm of the TFP of domestic firms in that industry drops by $0.1 * 3.407=0.3407$, or $34 \%$ of the sample mean. This magnitude is much larger than the OLS estimates in the literature (e.g., 0.0267 by 
Aitken and Harrison, 1999; 0.067 by Konings, 2001; 0.0106 by Lin, Liu, and Zhang, 2009). These results suggest that the OLS estimator is downward biased, possibly due to some omitted variables bias and/or measurement errors in the panel data framework.

To gain further insights into the economic significance of our estimate, we conduct the following exercise. Note that from 1998 to 2007, the average output-weighted share of FDI increases from 0.2062 to 0.2595 . According to our estimate, this increase of FDI share reduces the average logarithm of the TFP of domestic firms by $(0.2595-$ $0.2062) * 3.407=0.1816$ during this period. Meanwhile, the overall average logarithm of the TFP of domestic firms increases from 0.90 to 1.14 . Hence, if we set the outputweighted share of FDI in 2007 to be the same as in 1998, the average logarithm of the TFP of domestic firms increases a further $0.1816 / 1.14=15.93 \%$ from 1998 to 2007.

\section{How to Explain the Negative FDI Spillovers}

The previous section establishes that FDI causes a negative spillover effect on the productivity of domestic firms in the same industry. In this section, we explore the relevance of two hypotheses that are widely used to explain the negative FDI spillover effect. To save space, we only show the second stage results of the instrumental variable estimation; the first stage estimation results are available upon request.

\subsection{Agglomeration versus Competition}

Aitken and Harrison (1999) provide a framework for understanding the negative spillover effect of FDI on domestic firms. They argue that domestic firms can benefit from nearby foreign multinationals through knowledge spillovers (such as imitation of foreign multinationals' technologies, management practices, and market orientation), labor pooling (such as recruitment of employees who have had experience at those foreign multinationals), and supply of specialized inputs (for example, obtaining inputs from suppliers of foreign multinationals). Such a positive effect is usually referred to in the international and urban economics literature as the agglomeration effect. However, domestic firms may lose market share to the generally more productive foreign multinationals, and consequently experience a fall in firm productivity due to a lack of scale economies. Such a negative effect is often referred to as the competition effect.

To further understand how the competition and agglomeration effects determine the overall FDI spillovers on domestic firms, we explore variations in different dimen- 
sions of FDI, and examine scenarios under which these two underlying effects have different relative strengths, leading to possibly different overall FDI spillovers.

\subsubsection{FDI from Developed Countries vs. Developing Countries}

Foreign multinationals come from different countries with different technologies and know-how, and present different trade-offs to China's domestic firms. For example, FIEs from developing countries with a similar or even a lower level of economic development than China may not possess any advanced technology or sophisticated know-how for China's domestic firms to benefit from. At the same time, these FIEs might not be competitive enough to grab significant market shares from domestic firms. In contrast, FDI coming from developed countries is expected to generate a significant agglomeration effect; but precisely because of their latest technology and advanced know-how, FIEs from developed countries are in an ideal position to steal market share away from China's domestic firms, as can be seen in many industries (for example, automobile). Hence, the examination of possibly differential effects of FDI from developing and developed countries can reveal the interaction between the negative competition effect and positive agglomeration effect from FDI. ${ }^{22}$

To this end, we decompose the extent of FDI (FDI_Sector $i t)$ in industry $i$ at year $t$ into two components: the extent of FDI from developed countries (FDI_Sector_Developed $\left.d_{i t}\right)$ and the extent of FDI from developing countries $\left(F D I \_ \text {Sector_Developing } \overline{i t}^{-}\right)^{23}$ Specifically,

$$
\begin{aligned}
& F D I_{-} \text {Sector_Developed } d_{i t}=\frac{\sum_{f \in \Omega_{i t}} F D I_{-} \text {Firm__oveloped }_{f i 2001} \times \text { Output }_{f i t}}{\sum_{f \in \Omega_{i t}} \text { Output }_{f i t}} \\
& F D I_{-} \text {Sector_Developing } i t=\frac{\sum_{f \in \Omega_{i t}} \text { FDI_Firm_Developing } \text { fi2001 }_{\text {_t }} \times \text { Output }_{f i t}}{\sum_{f \in \Omega_{i t}} \text { Output }_{f i t}} \text {, }
\end{aligned}
$$

where FDI_Firm_Developed $f_{i 2001}$ and FDI_Firm_Developing fi2001 $_{\text {_re }}$ are the foreign equity of firm $\bar{f}$ of industry $i$ in 2001 from developed and developing countries, respectively.

\footnotetext{
${ }^{22}$ In a similar vein, Javorcik and Spatareanu (2011) study whether foreign investors from different countries (Europe versus North America) generate different spillovers to domestic suppliers, based on the argument that the share of local sourcing is affected by the geographic distance between the host and source countries of FDI and preferential trade agreements.

${ }^{23}$ The Ministry of Commerce Foreign Invested Firms Survey (FIFS) contains information on the country of origin of foreign firms. We use firm name and contact information to merge the FIFS country of origin data with the ASIF data, and classify countries into developed countries (i.e., high-income OECD members based on the World Bank criteria) and developing countries.
} 
Given that we have two potentially endogenous regressors of interest in the estimation, we need two instruments for their identification. The first regressor of interest reflects the variations in the extent of FDI from developed countries across industries and the second regressor of interest captures the variations in the extent of FDI from developing countries. Although the relaxation of FDI regulations upon China's WTO accession is uniform for developed and developing countries, the effects on FDI from the two different groups of countries could be different due to pre-existing conditions. To this end, we construct two instruments for FDI_Sector_Developed ${ }_{i t}$ and FDI_Sector_Developing $i t$ Treatment $_{i} \times$ Post $_{2} 2_{t}$ and $\overline{\text { Treatment }}_{i} \times$ Indicator $_{i 2001} \times$ Post $_{2} 2_{t}$, where Indicator $_{i 2001}$ equals 1 if industry $i$ 's foreign equity share from developed countries is above its median level in 2001 .

The instrumental variable estimation results are shown in column 1 of Table 4. Although both are statistically significant, the negative productivity effect of FDI from developed countries is stronger than that from developing countries. These results suggest that the negative competition effect is more dominant relative to the agglomeration effect for FDI from developed countries than for FDI from developing countries.

\section{[Insert Table 4 here]}

\subsubsection{Horizontal vs. Vertical FDI}

Javorcik (2004) demonstrates the importance of upstream and downstream linkages as potential channels for FDI to have positive effects on domestic firms. ${ }^{24}$ Intuitively, we do not expect any direct competition between domestic firms and foreign multinationals that are located in different vertical stages of the same production chain, and such foreign multinationals have more incentives to educate their domestic clients or suppliers. In other words, the agglomeration effect might dominate the competition effect for FDI located in either upstream or downstream industries.

To test this prediction, we follow Javorcik (2004) in constructing a domestic firm's backward and forward FDI_Sector. Specifically, for domestic firm $f$ of sector $s$ in year $t$, its backward FDI_Sector is

$$
F D I \_S e c t o r_{s t}^{b a c k w a r d}=\sum_{k \text { if } k \neq s} \alpha_{s k} \times F D I_{-} \text {Sector }_{k t}
$$

\footnotetext{
${ }^{24}$ This finding is further confirmed by papers using data from different countries, such as Bwalya (2006) for Zambia; Kugler (2006) for Colombia; Blalock and Gertler (2008) for Indonesia; Barrios, Görg, and Strobl (2011) for Ireland; Liu (2008), Lin, Liu, and Zhang (2009), and Du, Harrison, and Jefferson (2012) for China; and Damijan, Rojec, Majcen, and Knell (2013) and Gorodnichenko, Svejnar, and Terrell (2014) for several emerging and transition economies.
} 
where $\alpha_{s k}$ is the ratio of sector $s$ 's output supplied to sector $k$ (information compiled from the 2002 China's Input-Output Table). ${ }^{25}$ Its forward FDI_Sector is

$$
F D I_{-} \text {Sector } \text { forward }^{\text {for }}=\sum_{m \text { if } m \neq s} \beta_{s m} \times \frac{\sum_{j \in \Omega_{m t}} F D I_{-} \text {Firm }_{j t} \times\left(\text { Output }_{j t}-E X_{j t}\right)}{\sum_{j \in \Omega_{m t}}\left(\text { Output }_{j t}-E X_{j t}\right)},
$$

where $E X_{j t}$ is firm $j$ 's export at time $t$; Output $t_{j t}-E X_{j t}$ is the size of firm $j$ ' output working for domestic market; and $\beta_{s m}$ is the ratio of inputs purchased by sector $s$ from sector $m .^{26}$

Accordingly, the instruments for FDI_Sector ${ }_{s t}, F D I \_S e c t o r_{s t}^{\text {backward }}$, and FDI_Sector st $_{\text {st }}^{\text {forward }}$

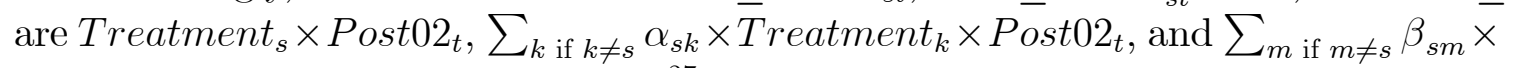

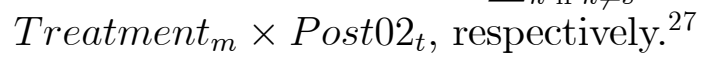

The instrumental variable estimation results are shown in column 2 of Table 4. The effect of horizontal FDI on firm productivity remains negative and significant. Interestingly, we find that the effects of both backward and forward FDI on firm productivity are positive and statistically significant. These results are consistent with the findings in the literature (e.g., Javorcik 2004) and confirm the argument that the agglomeration effect dominates the competition effect for FDI located in either upstream or downstream industries.

\subsubsection{Local vs. Non-Local FDI}

The competition and agglomeration effects of FDI exhibit different degrees of attenuation with distance. The agglomeration effect operates through knowledge spillovers and labor pooling, which are more likely to be captured by domestic firms located near foreign multinationals. ${ }^{28}$ In contrast, product markets are generally integrated within a country, and thus the competition effect does not decrease substantially with distance. ${ }^{29}$ As the positive agglomeration effect is relatively more localized than the negative competition effect, it is expected that domestic firms benefit from foreign

\footnotetext{
${ }^{25} \alpha_{s k}$ is calculated by excluding the products supplied for final consumption and the imports of intermediate products.

${ }^{26}$ The industries in the ASIF data are more disaggregated than the sectors in China's InputOutput (or IO) Table. Hence, we compile a concordance table to link 4-digit industries in the ASIF data with IO sectors, and to measure the extent of FDI, i.e., horizontal, backward, and forward FDI, at the broad level of IO sectors.

${ }^{27}$ The treatment dummy is aggregated from the 4-digit industries to the IO sectors by taking a simple average.

${ }^{28}$ For a recent review of this literature, see Audretsch and Feldman (2004).

${ }^{29}$ For a recent review of this literature, see Taylor and Taylor (2004).
} 
multinationals in the same industry that are located nearby, but may suffer from FDI located in more distant areas. This argument has been supported in previous studies, including Sjöholm (1999), Bwalya (2006), Halpern and Muraközy (2007), and $\mathrm{Xu}$ and Sheng (2012).

To test this prediction, we divide the extent of FDI in an industry into two parts: the extent of FDI located in the same city as the concerned domestic firm and the extent of FDI located outside of the city. Specifically,

$$
\begin{aligned}
& F D I_{-} \text {Sector_Local }{ }_{i t}=\frac{\sum_{f \in \Omega_{i c t}} F D I_{-} \text {Firm }_{\text {fict }} \times \text { Output }_{\text {fict }}}{\sum_{f \in \Omega_{i c t}} \text { Output }_{\text {fict }}} \\
& \text { FDI_Sector_Non-Local } I_{i t}=\frac{\sum_{f \in \Omega_{i t}} \text { FDI_Firm } \text { fit }_{\text {f }} \times \text { Output }_{f i t}}{\sum_{f \in \Omega_{i t}} \text { Output }_{f i t}-\sum_{f \in \Omega_{i c t}} \text { Output }_{\text {fict }}} \\
& -\frac{\sum_{f \in \Omega_{i c t}} \text { FDI_Firm }}{\text { fict }_{f} \times \text { Output }_{f i c t}},
\end{aligned}
$$

where $c$ denotes city. The instrumental variable for FDI_Sector_Local $l_{i t}$ is constructed as $\frac{\text { output }_{i c 2001} \times \text { Treatment }_{i} \times \text { Post } 02 t_{t}}{\sum_{i} \text { Output }_{i c 2001}}$, reflecting the localized effect of policy shock, whereas the instrument for FDI_Sector_Non-Local $l_{i t}$ is constructed as

$\frac{\left(\sum_{c} \text { Output }_{i c 2001} \times \text { Treatment }_{i} \times{\text { Post } 02_{t}}_{t}-\text { Output }_{i c 2001} \times \text { Treatment }_{i} \times{\text { Post } 02_{t}}_{t}\right.}{\sum_{i} \sum_{c} \text { Output }_{i c 2001}-\sum_{i} \text { Output }_{i c 2001}}$,

capturing the non-localized effect of policy shock. Here, Output $t_{i c 2001}$ is the total output of industry $i$ in city $c$ in 2001 .

The instrumental variable estimation results are shown in column 3 of Table 4. The productivity effect of FDI located in the same city is positive and statistically significant, whereas the productivity effect of FDI located outside the city remains negative and statistically significant. These results confirm our argument that the two opposite effects of FDI have different degrees of attenuation with distance, and that domestic firms are likely to benefit from horizontal FDI located nearby but to suffer from horizontal FDI located in more distant areas.

\subsubsection{Static vs. Dynamic Effects}

Kosová (2010) argues that the competition effect could be a short-term effect whereas the agglomeration effect may take time to become effective; in this case, the spillover 
effect of FDI on domestic firms could become positive in the growth rate estimations. Using firm-level data from the Czech Republic for the 1994 to 2001 period, she finds that growing foreign sales increases domestic firms' growth. This dynamic positive effect of FDI on domestic firms is also found by Liu (2008) and Merlevede, Schoors, and Spatareanu (2014).

Following this line of research, we investigate whether the presence of foreign multinationals has a positive effect on the growth rate of firm productivity (measured as one-year differenced firm productivity). The instrumental variable estimation results are shown in column 4 of Table 4 . We indeed find a positive effect of FDI on the productivity growth rate of domestic firms in the same industry, consistent with the findings in the literature. These results suggest that although the presence of foreign multinationals may hurt domestic firms in the short-run (by stealing their market share), they may benefit domestic firms in the long-run (through knowledge spillover, labor pooling, etc.).

\subsection{Absorptive Capacity}

Our analysis in Section 4.1 focuses on how various types of FDI differentially affect the agglomeration effect and competition effect, and hence the overall spillover effect of FDI on domestic firms. In this subsection we examine how the absorptive capacity of domestic firms may affect the FDI spillover effect.

Kokko (1994), using cross-sectional industry-level data from Mexico, tests the idea that FDI spillovers on domestic firms depend on the technological distance between the foreign multinationals and the domestic firms. The hypothesis that the degree of FDI spillover hinges on the absorptive capacity of domestic firms has been further explored in the literature. For example, Blalock and Gertler (2009), using a panel dataset of Indonesian manufacturing firms for the 1988 to 1996 period, find that firms with more R\&D investment benefit more from the presence of foreign multinationals. Lin, Liu, and Zhang (2009) find that the negative effect of FDI on firm productivity is smaller for Chinese SOEs than for other domestic non-SOEs, presumably because state-owned enterprises in China are better endowed and more capable of absorbing technology and know-how from foreign multinationals than their privately-owned counterparts.

To investigate the role of absorptive capacity in explaining the negative effect of FDI on domestic firms, we further conduct two exercises: 1) we investigate whether the FDI spillovers differ across firms with different R\&D investments; and 2) we examine any differential FDI effects across firms with different ownership structures (i.e., SOEs vs. non-SOEs). We use the changes in FDI regulations at the end of 2001 
to instrument the presence of foreign multinationals. To mitigate the estimation bias that may occur because those changes in FDI regulations in turn affected firms' R\&D decisions and ownership structure, we measure the R\&D investment ratio and ownership structure using information from 2001, one year before the changes in FDI regulations. The estimation results are reported in Table 5.

\section{[Insert Table 5 here]}

$R \mathscr{E} D$ investment. In column 1 , we present the instrumental variable estimation results for whether the FDI spillovers differ across firms with different ratios of R\&D investment over total output (denoted by $R \& D$ Intensity) in 2001 . The single term of FDI_Sector $i t$ is still negative and statistically significant, but the interaction between FDI_Sector ${ }_{i t}$ and R\&D Intensity is small in magnitude and statistically insignificant. These results imply that foreign multinationals have a negative effect on firms without R\&D investment, but this negative effect does not improve much for firms that have R\&D investment.

Ownership structure. We further investigate whether the FDI spillovers differ between SOEs and other domestic non-SOEs in China; the results are shown in column 2. The presence of foreign multinationals has negative and statistically significant effects on both SOEs and other domestic non-SOEs, and the difference between these two groups is small, although statistically significant. These results suggest that the difference between state and private ownership may not explain why FDI has a negative spillover effect on the productivity of China's domestic firms.

\section{Other Measures of Firm Performance}

The above analyses focus on productivity as the measurement of firm performance. It is possible that domestic firms could benefit from the presence of foreign multinationals in aspects other than production efficiency. In this section, we consider some of the other measures of firm performance used in studies of FDI spillovers. The second stage results of the instrumental variable estimation are presented in Table 6 ; the first stage estimation results are available upon request.

$$
\text { [Insert Table } 6 \text { here] }
$$

Exporting performance. We examine whether the presence of foreign multinationals helps domestic firms in the same industry to export. Presumably, domestic firms could obtain information about the international market from foreign multinationals, 
thus reducing the entry barriers to the international market. Indeed, Aitken, Hanson, and Harrison (1997) find, using plant-level cross-sectional data from Mexican manufacturing industries, that the export activities of foreign multinationals increase the probability of exporting by domestic firms in the same industry. This finding is further confirmed by other studies, such as Barrios, Görg, and Strobl (2003), Greenaway, Sousa, and Wakelin (2004), and Banga (2006).

Following this line of research, we look at two measures of exporting performance: the probability of exporting and export intensity. The regression results are shown in columns 1-2 of Table 6. Domestic firms do not have either a higher probability of exporting or a greater exporting intensity when there are more foreign multinationals in the same industry. These results are in sharp contrast to the findings reported by studies using the OLS estimations, and indicate that export activities may not be an alternative channel for benefits to domestic firms from the presence of multinationals.

Wage rate. Next, we investigate the FDI effect on the wage rate of domestic firms. The premise is that there could be some FDI spillovers on labor productivity (such as human capital, managerial experience, etc.), but not on the overall production efficiency. Aitken, Harrison, and Lipsey (1996) find a positive effect of FDI on the wage rate in the U.S. but negative effects in Mexico and Venezuela. Using matched employer-employee data from Brazil, Poole (2013) conducts a worker-level analysis and finds that workers benefit from colleagues who have some experience at foreign multinationals.

However, a limitation of using the wage rate to capture the labor productivity effect of FDI is that foreign multinationals and domestic firms are competing in the same labor market, and hence an increase in wage rate may not be related to any positive spillovers from FDI to domestic firms. With this caveat in mind, we examine the effect of FDI on the wage rate in our dataset. The regression results are shown in column 3 of Table 6 . We find that domestic firms increase their wage rates when there are more foreign multinationals in the same industry. Given that higher wages imply better labor forces, this finding provides some evidence that domestic firms may benefit from foreign multinationals by getting access to employees with better human capital and more managerial experience.

RESD investment. We further investigate whether the entry of FIEs spurs domestic firms in the same industry to engage in innovative activities. Theoretically, the effect of FDI on the innovative activities of domestic firms could be mixed. On the one hand, the $\mathrm{R} \& \mathrm{D}$ productivity of domestic firms may be enhanced by the presence of foreign multinationals through channels such as knowledge spillovers and labor pooling, and this may lead to greater R\&D investment. On the other hand, 
the presence of foreign multinationals may discourage domestic firms from investing in $R \& D$, as they foresee less chance of beating the foreign multinationals in the race for new products. In the context of China, Cheung and Lin (2004) show in a panel of provincial data for the 1995 to 2000 period that FDI has a positive effect on domestic patent filings.

In our dataset, we only have the R\&D expenditure data for a few years, and hence we use the ratio of new product revenue as a proxy for firms' innovative activities. The estimation results are shown in column 4 of Table 6. Although the estimated coefficient is positive, it is not significant and is small in magnitude, suggesting that domestic firms do not increase their innovative activities when there are more foreign multinationals in the same industry.

Firm survival. Lastly, we examine whether the presence of foreign multinationals increases or decreases the probability of firm survival, the underpinnings of job creation and destruction. Görg and Strobl (2003), studying Irish manufacturing plants, find that the presence of foreign multinationals enhances the survival probability of domestic firms in high-tech industries. Kosová (2010) further confirms the positive effect of FDI on firm survival for firms in the Czech Republic for the 1994 to 2001 period. However, using data from Belgian manufacturing industries, De Backer and Sleuwaegen (2003) find that FDI drives out domestic entrepreneurs.

To test this hypothesis, we first construct a dummy variable (denoted Exit) indicating whether a domestic firm exited the dataset in the following year or not, and then conduct an instrumental variable estimation using this outcome variable. The regression results are shown in column 5 of Table 6 . We find that the presence of FDI in the same industry has a negative effect on the firm exit rate: increasing the output-weighted FDI share in an industry by 10 percentage points increases the survival probability of domestic firms in that industry by 2.6 percentage points; these results are consistent with Kosová's findings (2010).

\section{Conclusion}

It is notoriously hard to identify the FDI spillovers on domestic firms, as the decision by foreign multinationals to enter developing countries and their various industries is obviously an endogenous one. This partially explains why there is no consensus on the effect of horizontal FDI on domestic firms. However, these mixed findings are troubling, as the governments of developing countries have been urged by both developed countries and international organizations to open up their economies to foreign direct investment. This paper contributes to the literature by utilizing the 
arguably exogenous relaxation of FDI regulations upon China's accession to the WTO, under which some of China's manufacturing industries became more open to foreign direct investment (the treatment group) while others encountered no change in FDI regulations (the control group). We find that the former group of industries experienced significantly larger inflows of FDI than the latter, although there had been little difference between the two groups prior to China's entry into the WTO. Using instrumental variable estimations, we find that FDI has a negative and significant effect on the productivity of domestic firms in the same industry. In addition, this paper investigates the two underlying effects (the agglomeration effect and the competition effect) involved in FDI spillovers on domestic firms. Using variations along dimensions of foreign direct investment, and differences in the absorptive capacities of domestic firms, we study various scenarios in which the two underlying effects have different relative strengths, thereby leading to possibly different overall FDI spillovers. Finally, we use an array of measures used in the literature (including TFP, exporting performance, wages, R\&D investment, and firm survival) to examine the effect of horizontal FDI on domestic firms, therefore offering a fuller picture of the specific areas where domestic firms may benefit or suffer from the presence of foreign multinationals.

\section{References}

[1] Ackerberg, Daniel A., Kevin Caves, and Garth Frazer, 2015. Identification properties of recent production function estimators. Econometrica. (forthcoming).

[2] Aitken, Brian J., and Ann E. Harrison, 1999. Do domestic firms benefit from direct foreign investment? evidence from Venezuela. American Economic Review. $89(3), 605-618$.

[3] Aitken, Brian J., Ann E. Harrison, and Robert E. Lipsey, 1996. Wages and foreign ownership a comparative study of Mexico, Venezuela, and the United States. Journal of International Economics. 40(3), 345-371.

[4] Aitken, Brian J., Gordon H. Hanson, and Ann E. Harrison, 1997. Spillovers, foreign investment, and export behavior. Journal of International Economics. 43(1), 103-132.

[5] Audretsch, David B., and Maryann P. Feldman, 2004. Knowledge spillovers and the geography of innovation. Handbook of Regional and Urban Economics. 4, $2713-2739$. 
[6] Balsvik, Ragnhild, 2011. Is labor mobility a channel for spillovers from multinationals? evidence from Norwegian manufacturing. Review of Economics and Statistics. 93(1), 285-297.

[7] Banga, Rashmi, 2006. The export-diversifying impact of Japanese and US foreign direct investments in the Indian manufacturing sector. Journal of International Business Studies. 37(4), 558-568.

[8] Barrios, Salvador, Holger Görg, and Eric Strobl, 2003. Explaining firms' export behaviour: R\&D, spillovers and the destination market. Oxford Bulletin of Economics and Statistics. 65(4), 475-496.

[9] Barrios, Salvador, Holger Görg, and Eric Strobl, 2011. Spillovers through backward linkages from multinationals: measurement matters! European Economic Review. 55(6), 862-875.

[10] Bertrand, Marianne, Esther Duflo, and Sendhil Mullainathan, 2004. How much should we trust differences-in-differences estimates? Quarterly Journal of Economics. 119(1), 249-275.

[11] Blalock, Garrick, and Paul J. Gertler, 2008. Welfare gains from foreign direct investment through technology transfer to local suppliers. Journal of International Economics. 74(2), 402-421.

[12] Blalock, Garrick, and Paul J. Gertler, 2009. How firm capabilities affect who benefits from foreign technology. Journal of Development Economics. 90(2), 192199.

[13] Blomström, Magnus, and Ari Kokko, 1998. Multinational corporations and spillovers. Journal of Economic Surveys. 12(3), 247-277.

[14] Brandt, Loren, Johannes Van Biesebroeck, and Yifan Zhang, 2012. Creative accounting or creative destruction? firm-level productivity growth in Chinese manufacturing. Journal of Development Economics. 97(2), 339-351.

[15] Bwalya, Samuel Mulenga, 2006. Foreign direct investment and technology spillovers: evidence from panel data analysis of manufacturing firms in Zambia. Journal of Development Economics. 81(2), 514-526.

[16] Cheung, Kui-yin, and Ping Lin, 2004. Spillover effects of FDI on innovation in China: evidence from the provincial data. China Economic Review. 15(1), 25-44. 
[17] Damijan, Jože P., Matija Rojec, Boris Majcen, and Mark Knell, 2013. Impact of firm heterogeneity on direct and spillover effects of FDI: micro-evidence from ten transition countries. Journal of Comparative Economics. 41(3), 895-922.

[18] De Backer, Koen, and Leo Sleuwaegen, 2003. Does foreign direct investment crowd out domestic entrepreneurship? Review of Industrial Organization. 22(1), $67-84$.

[19] Djankov, Simeon, and Bernard Hoekman, 2000. Foreign investment and productivity growth in Czech enterprises. World Bank Economic Review. 14(1), 49-64.

[20] Du, Luosha, Ann E. Harrison, and Gary H. Jefferson, 2012. Testing for horizontal and vertical foreign investment spillovers in China, 1998-2007. Journal of Asian Economics. 23(3), 234-243.

[21] Gentzkow, Matthew, 2006. Television and voter turnout. Quarterly Journal of Economics. 121(3), 931-972.

[22] Girma, Sourafel, 2005a. Absorptive capacity and productivity spillovers from FDI: a threshold regression analysis. Oxford Bulletin of Economics and Statistics. 67(3), 281-306.

[23] Girma, Sourafel, 2005b. Technology transfer from acquisition FDI and the absorptive capacity of domestic firms: an empirical investigation. Open Economies Review. 16(2), 175-187.

[24] Görg, Holger, and David Greenaway, 2004. Much ado about nothing? do domestic firms really benefit from foreign direct investment? World Bank Research Observer. 19(2), 171-197.

[25] Görg, Holger, and Eric Strobl, 2001. Multinational companies and productivity spillovers: a meta-analysis. Economic Journal. 111(475), 723-739.

[26] Görg, Holger, and Eric Strobl, 2003. Multinational companies, technology spillovers and plant survival. Scandinavian Journal of Economics. 105(4), 581595.

[27] Görg, Holger, and Eric Strobl, 2007. The effect of R\&D subsidies on private R\&D. Economica, 74(294), 215-234. 
[28] Gorodnichenko, Yuriy, Jan Svejnar, and Katherine Terrell, 2014. When does FDI have positive spillovers? evidence from 17 transition market economies. Journal of Comparative Economics. 42(4), 954-969.

[29] Greenaway, David, Nuno Sousa, and Katharine Wakelin, 2004. Do domestic firms learn to export from multinationals? European Journal of Political Economy. 20(4), 1027-1043.

[30] Haddad, Mona, and Ann E. Harrison, 1993. Are there positive spillovers from direct foreign investment? evidence from panel data for Morocco. Journal of Development Economics. 42(1), 51-74.

[31] Halpern, Lázló, and Balázs Muraközy, 2007. Does distance matter in spillover? Economics of Transition. 15(4), 781-805.

[32] Haskel, Jonathan E., Sonia C. Pereira, and Matthew J. Slaughter, 2007. Does inward foreign direct investment boost the productivity of domestic firms? Review of Economics and Statistics. 89(3), 482-496.

[33] Hu, Albert G.Z., and Gary H. Jefferson, 2002. FDI impact and spillover: evidence from China's electronic and textile industries. World Economy. 25(8), 10631076 .

[34] Javorcik, Beata S., 2004. Does foreign direct investment increase the productivity of domestic firms? in search of spillovers through backward linkages. American Economic Review. 94(3), 605-627.

[35] Javorcik, Beata S., and Mariana Spatareanu, 2011. Does it matter where you come from? vertical spillovers from foreign direct investment and the origin of investors. Journal of Development Economics. 96(1), 126-138.

[36] Keller, Wolfgang, and Stephen R. Yeaple, 2009. Multinational enterprises, international trade, and productivity growth: firm-level evidence from the United States. Review of Economics and Statistics. 91(4), 821-831.

[37] Kokko, Ari, 1994. Technology, market characteristics, and spillovers. Journal of Development Economics. 43(2), 279-293.

[38] Konings, Jozef, 2001. The effects of foreign direct investment on domestic firms. Economics of Transition. 9(3), 619-633. 
[39] Kosová, Renáta, 2010. Do foreign firms crowd out domestic firms? evidence from the Czech Republic. Review of Economics and Statistics. 92(4), 861-881.

[40] Kugler, Maurice, 2006. Spillovers from foreign direct investment: within or between industries? Journal of Development Economics. 80(2), 444-477.

[41] Lin, Ping, Zhuomin Liu, and Yifan Zhang, 2009. Do Chinese domestic firms benefit from FDI inflow? evidence of horizontal and vertical spillovers. China Economic Review. 20(4), 677-691.

[42] Liu, Zhiqiang, 2008. Foreign direct investment and technology spillovers: theory and evidence. Journal of Development Economics. 85(1-2), 176-193.

[43] Lu, Jiangyong, Yi Lu, and Zhigang Tao, 2010. Exporting behavior of foreign affiates: theory and evidence. Journal of International Economics. 81(2), 197205.

[44] Lu, Yi, and Linhui Yu, 2015. Trade liberalization and markup dispersion: evidence from China's WTO accession. American Economic Journal: Applied Economics. 7(4), 221-253.

[45] Merlevede, Bruno, Koen Schoors, and Mariana Spatareanu, 2014. FDI spillovers and time since foreign entry. World Development. 56, 108-126.

[46] Poole, Jennifer P., 2013. Knowledge transfers from multinational to domestic firms: evidence from worker mobility. Review of Economics and Statistics. 95(2), 393-406.

[47] Sjöholm, Fredrik, 1999. Technology gap, competition and spillovers from direct foreign investment: evidence from establishment data. Journal of Development Studies. 36(1), 53-73.

[48] Taylor, Alan M., and Mark P. Taylor, 2004. The purchasing power parity debate. Journal of Economic Perspectives. 18(4), 135-158.

[49] Xu, Xinpeng, and Yu Sheng, 2012. Are FDI spillovers regional? firm-level evidence from China. Journal of Asian Economics. 23(3), 244-258. 


\section{Appendix}

\section{Appendix A: Determinants of Changes in FDI Regulations}

To some extent, the changes in FDI regulations upon China's WTO accession in 2002 may not be randomly determined. This presents an identification issue that the treatment and control groups were not comparable before the changes in FDI regulations, which may potentially bias our DID estimation. Meanwhile, there is a reverse causality problem that productivity of China's domestic firms may affect its government's decision in modifying FDI regulations, which may also cause estimation biases. In this appendix, we carefully examine the determinants of the changes in FDI regulations upon China's WTO accession in addressing these issues.

There are many reasons why the government decided to modify the Catalogue for the Guidance of Foreign Investment Industries in 2002. It is widely acknowledged that the central government of China was keen in making its domestic firms competitive in the era of globalization. According to the Xinhua News released on March 12, 2002, the government relaxed the FDI regulations for certain industries in order to promote industry upgrading and exports. Meanwhile, the government may protect infant industries in their early stages and encourage industrial clustering so as to boost development in those industries. Finally, the government also cares about how the relaxation of FDI regulations may impact on labor market conditions, such as current employment and wages, which is critical for maintaining social stability in China.

To account for the above possible considerations of China's government in relaxing its FDI regulations, we include seven variables: new product intensity (the ratio of new products in the total output), export intensity (the ratio of exports to total output), number of firms, industrial clustering (the Ellison-Glaeser index), average age of firms, average employment, and average wage per worker.

The regression results are reported in column 1 of Table A2, in which the changes in FDI regulations (a dummy variable taking value 1 if FDI in an industry became more welcome, and 0 othewise) are regressed on the aforementioned seven potential determinants in year 1998, the initial year of the data available in our sample period. It is found that four variables are statistically significant: (1) new product intensity is found to have a positive effect; (2) export intensity is found to have a negative effect; (3) number of firms is found to have a positive effect; and (4) average age of firms is found to have a negative effect.

We further add a control of total factor productivity (TFP) in the regression to

account for the potential reverse causality issue that the changes in FDI regulations 
may be reversely affected by TFP. As shown in column 2, the coefficient of TFP is not statistically significant, with magnitude close to zero. This result indicates that changes in FDI regulations are not reversely affected by TFP.

\section{Appendix B: Estimation of Firm TFP}

Consider the following Cobb-Douglas production function in logs:

$$
y_{f t}=\beta_{l} l_{f t}+\beta_{k} k_{f t}+\beta_{m} m_{f t}+\omega_{f t}+\epsilon_{f t},
$$

where $y_{f t}$ is the log of firm output, $l_{f t}, k_{f t}$, and $m_{f t}$ are the inputs of log employment, $\log$ capital, and $\log$ materials. $\omega_{f t}$ is firm productivity, and $\epsilon_{f t}$ is measurement error and/or unanticipated shocks to output.

To obtain consistent production function estimates $\boldsymbol{\beta}=\left(\beta_{l}, \beta_{k}, \beta_{m}\right)$, we need to control for unobserved productivity shocks potentially leading to simultaneity and selection biases. We use a control function based on a static input demand function to proxy for the unobserved productivity.

We follow the control function approach initiated by Olley and Pakes (1996), and extended by Levinsohn and Petrin (2003), and De Loecker and Warzynski (2012), and proxy for the unobserved productivity using materials demand function:

$$
m=m_{t}\left(\omega_{f t}, k_{f t}, E X P_{f t}\right) .
$$

where $E X P_{f t}$ is firm's export status. Inverting (A2) yields the control function for productivity:

$$
\omega_{f t}=h_{t}\left(k_{f t}, m_{f t}, E X P_{f t}\right) .
$$

In the first stage, we purge unanticipated shocks and/or measurement error $\epsilon_{f t}$ by estimating the following equation:

$$
y_{f t}=\phi_{t}\left(l_{f t}, k_{f t}, m_{f t}, E X P_{f t}\right)+\epsilon_{f t}
$$

which yields an estimate of predicted output $\left(\hat{\phi}_{f t}\right)$.

We use (A1) and (A3) from the first stage estimation to express productivity:

$$
\omega_{f t}(\boldsymbol{\beta})=\hat{\phi}_{f t}-\beta_{l} l_{i t}-\beta_{k} k_{i t}-\beta_{m} m_{i t} .
$$

To estimate production function coefficients $\boldsymbol{\beta}$, we follow Ackerberg, Caves, and Frazer (2015) and form moments based on innovation in the productivity shock $\xi_{f t}$ 
in law of motion for productivity: ${ }^{30}$

$$
\omega_{f t}=g\left(\omega_{f t-1}, E X P_{f t}\right)+\xi_{f t} .
$$

We use (A4) and nonparametrically regress of $\omega_{f t}(\boldsymbol{\beta})$ on $g\left(\omega_{f t-1}, E X P_{f t}\right)$ to obtain the innovation $\xi_{f t}(\boldsymbol{\beta})=\omega_{f t}(\boldsymbol{\beta})-E\left(\omega_{f t}(\boldsymbol{\beta}) \mid \omega_{f t-1}(\boldsymbol{\beta}), E X P_{f t-1}\right)$.

The moment conditions used to estimate production function coefficients are:

$$
E\left(\xi_{f t}(\boldsymbol{\beta}) \mathbf{Y}_{f t}\right)=0,
$$

where $\mathbf{Y}_{f t}$ contains lagged labor and materials, and current capital. ${ }^{31}$

Once the production function coefficients $\hat{\boldsymbol{\beta}}=\left(\hat{\beta}_{l}, \hat{\beta}_{k}, \hat{\beta}_{m}\right)$ are estimated, we can compute firm productivity as follows:

$$
\hat{\omega}_{f t}=\hat{\phi}_{f t}-\hat{\beta}_{l} l_{i t}-\hat{\beta}_{k} k_{i t}-\hat{\beta}_{m} m_{i t} .
$$

\section{References}

[1] Ackerberg, Daniel A., Kevin Caves, and Garth Frazer, 2015. Identification properties of recent production function estimators. Econometrica. (forthcoming).

[2] De Loecker, Jan, 2013. Detecting learning by exporting. American Economic Journal: Microeconomics. 5(3), 1-21.

[3] De Loecker, Jan, and Frederic Warzynski, 2012. Markups and firm-level export status. American Economic Review. 102(6), 2437-2471.

[4] Levinsohn, James A., and Amil Petrin, 2003. Estimating production functions using inputs to control for unobservables. Review of Economic Studies. 70(2), 317341.

[5] Olley, Stephen G., and Ariel Pakes, 1996. The dynamics of productivity in the telecommunications equipment industry. Econometrica. 64(6), 1263-1297.

\footnotetext{
${ }^{30}$ As in De Loecker (2013), we include firm's export status in the law of motion for productivity to account for the potential effect of exporting on productivity.

${ }^{31}$ Following the literature, we treat labor and materials as flexible inputs and their lagged values are used to construct moments. As capital is considered as a dynamic input that faces adjustment costs, its current value is used to form moments.
} 
Figure 1: Foreign direct investment (realized) (1979-2007)

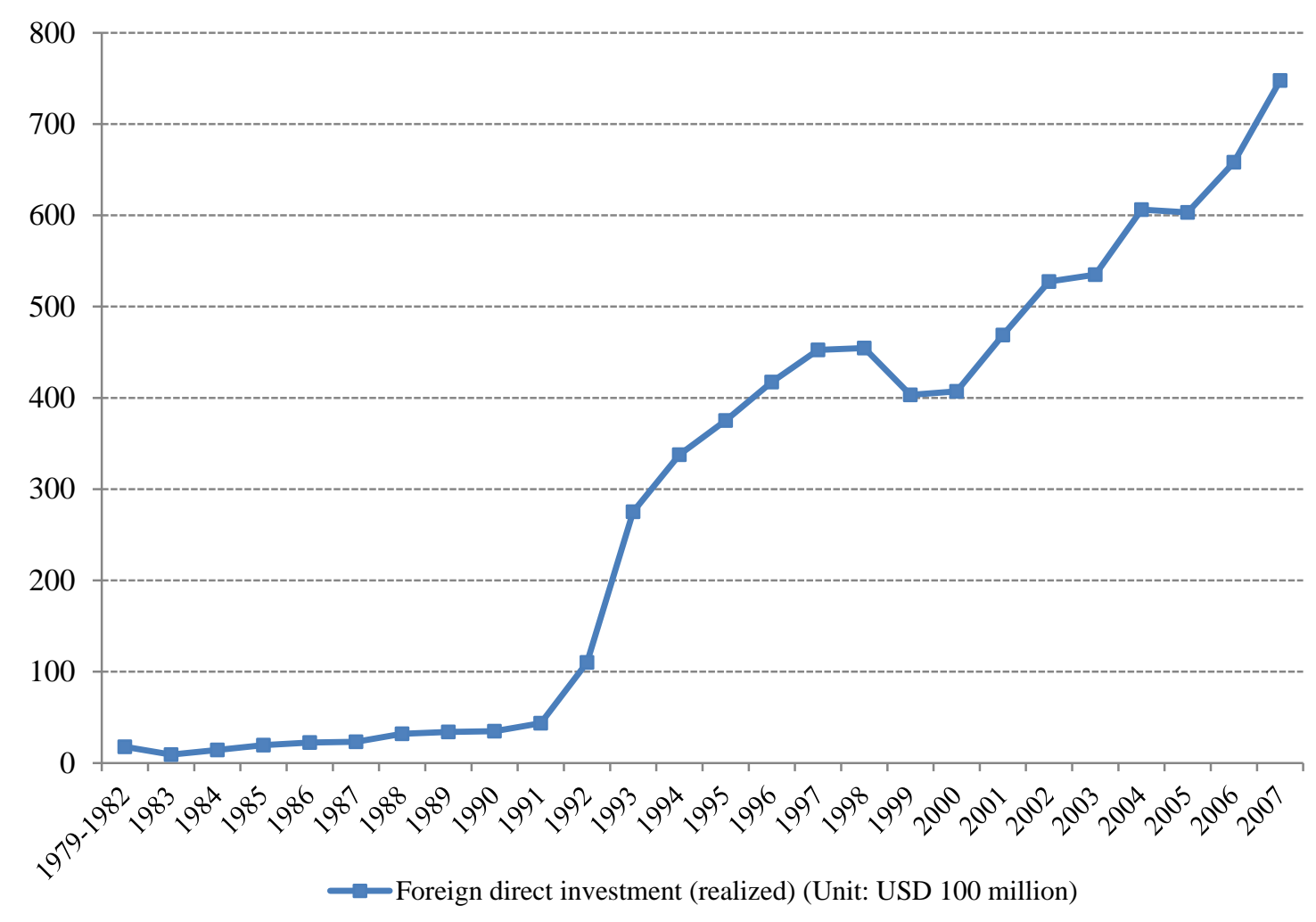

Note: The data on foreign direct investment are obtained from China Foreign Economic Statistical Yearbook (various years). 
Figure 2: Effect of FDI regulations on firm TFP

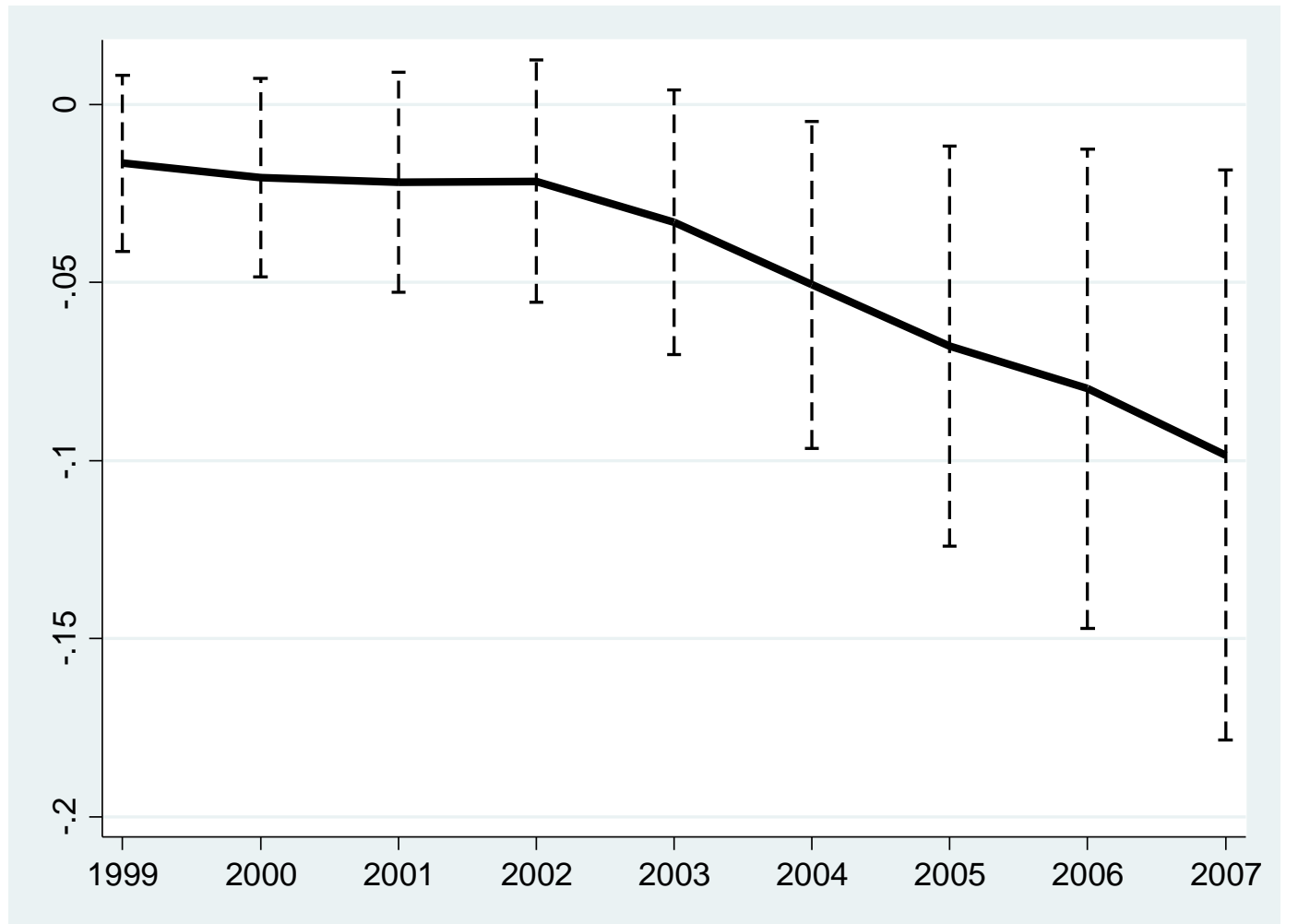

Note: The solid line captures the time course of the total factor productivity difference between industries that were opened up for FDI in the end of 2001 (treatment group) and those that did not (control group). The dashed line represents the 95\% confidence interval of the estimated effect. 
Figure 3: Distribution of estimates in the randomization test

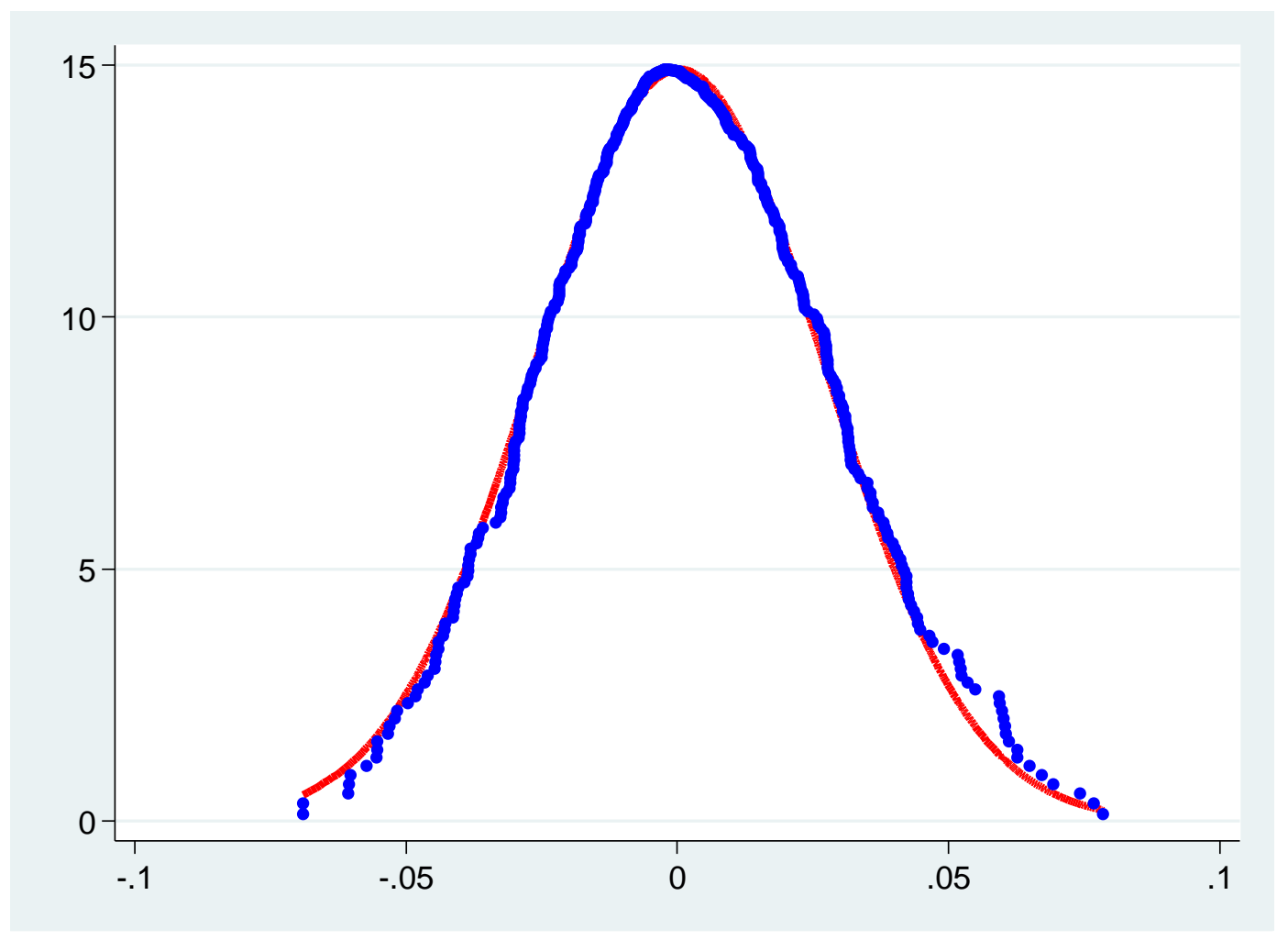

Note: In this exercise, we randomly assign the timing and the degree of changes in FDI regulations to industries (false Post02 and false Treatment dummy). We then use equation (1) to conduct regression analysis based on the false Post02 and false Treatment dummy. This is repeated 500 times and the resulting estimated coefficients are plotted. The figure shows the distribution of the estimates from the 500 times of randomization. 
Table 1: Foreign equity share at 2-digit industry level

\begin{tabular}{|c|c|c|c|}
\hline \multirow{2}{*}{ Industry } & \multicolumn{3}{|c|}{ Foreign equity share } \\
\hline & $1998-2007$ & $1998-2001$ & $2002-2007$ \\
\hline Food processing & 0.199 & 0.189 & 0.206 \\
\hline Food manufacturing & 0.276 & 0.257 & 0.288 \\
\hline Beverage manufacturing & 0.252 & 0.232 & 0.264 \\
\hline Tobacco processing & 0.014 & 0.018 & 0.011 \\
\hline Textile industry & 0.209 & 0.196 & 0.217 \\
\hline Garments \& other fiber products & 0.426 & 0.438 & 0.419 \\
\hline Leather, furs, down \& related products & 0.340 & 0.341 & 0.339 \\
\hline Timber processing, bamboo, cane, palm fiber \& straw products & 0.168 & 0.183 & 0.158 \\
\hline Furniture manufacturing & 0.418 & 0.386 & 0.440 \\
\hline Papermaking \& paper products & 0.225 & 0.219 & 0.230 \\
\hline Printing industry & 0.259 & 0.278 & 0.247 \\
\hline Cultural, educational \& sports goods & 0.409 & 0.386 & 0.424 \\
\hline Petroleum processing \& coking & 0.077 & 0.062 & 0.088 \\
\hline Raw chemical materials \& chemical products & 0.199 & 0.166 & 0.222 \\
\hline Medical \& pharmaceutical products & 0.181 & 0.174 & 0.187 \\
\hline Chemical fiber & 0.154 & 0.149 & 0.158 \\
\hline Rubber products & 0.242 & 0.213 & 0.261 \\
\hline Plastic products & 0.341 & 0.341 & 0.341 \\
\hline Nonmetal mineral products & 0.145 & 0.141 & 0.148 \\
\hline Smelting \& pressing of ferrous metals & 0.067 & 0.062 & 0.069 \\
\hline Smelting \& pressing of nonferrous metals & 0.064 & 0.061 & 0.066 \\
\hline Metal products & 0.255 & 0.250 & 0.258 \\
\hline Ordinary machinery & 0.177 & 0.151 & 0.194 \\
\hline Special purpose equipment & 0.171 & 0.121 & 0.204 \\
\hline Transport equipment & 0.133 & 0.119 & 0.142 \\
\hline Electric equipment \& machinery & 0.318 & 0.284 & 0.340 \\
\hline Electronic \& telecommunications equipment & 0.556 & 0.508 & 0.588 \\
\hline Instruments, meters, cultural \& office equipment & 0.388 & 0.342 & 0.418 \\
\hline Other manufacturing & 0.333 & 0.350 & 0.322 \\
\hline
\end{tabular}

Note: Output-weighted average of foreign equity share across all firms in each 2-digit industry calculated over the 1998-2007 period, the pre-WTO 1998-2001 period, and the post-WTO 2002-2007 period, respectively. 
Table 2: Summary statistics

\begin{tabular}{lccc}
\hline \hline \multicolumn{4}{c}{ Panel A. Firm-level variables } \\
\hline Variables & Obs. & Mean & Std. Dev. \\
\hline (log) firm TFP & $1,368,957$ & 1.026 & 0.432 \\
Export status & $1,368,957$ & 0.187 & 0.390 \\
Export intensity & $1,368,957$ & 0.101 & 0.270 \\
$(\log )$ wage rate & $1,365,869$ & 2.302 & 0.694 \\
New product intensity & $1,197,222$ & 0.031 & 0.140 \\
\hline \multicolumn{4}{c}{ Panel B. Industry-level variables } \\
\hline Variables & Obs. & Mean & Std. Dev. \\
\hline FDI sector (4-digit industry level) & 4,101 & 0.239 & 0.185 \\
Backward FDI (IO sector level) & 690 & 0.112 & 0.101 \\
Forward FDI (IO sector level) & 690 & 0.086 & 0.071 \\
\hline \hline
\end{tabular}

Note: Panel A reports number of observations, mean, and standard deviation on firm-level variables: firm TFP, export status, export intensity, wage rate, and new product intensity. Panel B reports number of observations, mean, and standard deviation on industry-level variables: FDI sector, backward FDI, and forward FDI. 
Table 3: Main results

\begin{tabular}{lcccc}
\hline \hline & $(1)$ & $(2)$ & $(3)$ & $(4)$ \\
\hline Panel A. First-stage. & \multicolumn{5}{c}{ Dependent variable: FDI sector } \\
\hline Treatment $\times$ Post02 & $0.014^{* *}$ & $0.014^{* *}$ & $0.014^{* *}$ & $0.014^{* *}$ \\
& $(0.007)$ & $(0.007)$ & $(0.007)$ & $(0.007)$ \\
\hline Panel B. Second-stage. & \multicolumn{5}{c}{ Dependent variable: $(\log )$ firm TFP } \\
\hline FDI sector & $-3.414^{* * *}$ & $-3.396^{* * *}$ & $-3.407^{* * *}$ & $-3.412^{* * *}$ \\
& $(0.115)$ & $(0.114)$ & $(0.114)$ & $(0.124)$ \\
\hline & & & & \\
Firm fixed effects & $\mathrm{Y}$ & $\mathrm{Y}$ & $\mathrm{Y}$ & $\mathrm{Y}$ \\
Year fixed effects & $\mathrm{Y}$ & $\mathrm{Y}$ & $\mathrm{Y}$ & $\mathrm{Y}$ \\
& $\mathrm{Y}$ & $\mathrm{Y}$ & $\mathrm{Y}$ & $\mathrm{Y}$ \\
FDI determinants $\times$ Year dummies & $\mathrm{Y}$ & $\mathrm{Y}$ & $\mathrm{Y}$ & $\mathrm{Y}$ \\
Tariff reductions $\times$ Year dummies & $\mathrm{N}$ & $\mathrm{Y}$ & $\mathrm{Y}$ & $\mathrm{Y}$ \\
SOE privatization $\times$ Year dummies & $\mathrm{N}$ & $\mathrm{N}$ & $\mathrm{Y}$ & $\mathrm{Y}$ \\
Time-varying firm controls & $1,368,957$ & $1,368,957$ & $1,368,957$ & $1,360,262$ \\
\hline Observations & \multicolumn{5}{c}{. }
\end{tabular}

Note: Panels A and B report the results of first and second-stage IV estimation, respectively. In columns 1-3, the sample for our analysis is that of domestic firms. In column 4, domestic processing traders are excluded from our analysis. Determinants of changes in FDI regulations include new product intensity, export intensity, number of firms, and average age of firms at the 4-digit industry level in 1998. Tariff reductions include output tariff, input tariff, and export tariff at the 4-digit industry level in 2001. SOE privatization is a ratio of state-owned enterprises in the total number of firms at the 4-digit industry level in 2001. Time-varying firm controls include firm output, export status, capital-labor ratio, and SOE dummy. In Panel A, robust standard errors are clustered at the 4-digit industry level in parenthese. In Panel B, bootstrapped standard errors are clustered at the 4-digit industry level in parenthese. ${ }^{* *}, * *$ and $*$ denote significance at the 1,5 and $10 \%$ level respectively. 
Table 4: Agglomeration versus competition effects

\begin{tabular}{|c|c|c|c|c|}
\hline Dependent variable: $(\log )$ firm TFP & $\begin{array}{l}\text { Developed vs. } \\
\text { developing FDI }\end{array}$ & $\begin{array}{l}\text { Horizontal vs. } \\
\text { vertical FDI }\end{array}$ & $\begin{array}{l}\text { Local vs. Non- } \\
\text { local FDI }\end{array}$ & TFP growth \\
\hline & (1) & (2) & (3) & (4) \\
\hline$\overline{\text { FDI sector (developed) }}$ & $\begin{array}{c}-7.318^{* * *} \\
(0.454)\end{array}$ & & & \\
\hline FDI sector (developing) & $\begin{array}{c}-2.802 * * * \\
(0.157)\end{array}$ & & & \\
\hline FDI sector (horizontal FDI) & & $\begin{array}{c}-3.919 * * * \\
(0.051)\end{array}$ & & $\begin{array}{c}1.213 * * * \\
(0.148)\end{array}$ \\
\hline Backward FDI & & $\begin{array}{c}0.541 * * * \\
(0.040)\end{array}$ & & \\
\hline Forward FDI & & $\begin{array}{c}3.855 * * * \\
(0.078)\end{array}$ & & \\
\hline FDI sector (local) & & & $\begin{array}{c}6.644 * * * \\
(1.642)\end{array}$ & \\
\hline FDI sector (non-local) & & & $\begin{array}{c}-6.329 * * * \\
(0.933)\end{array}$ & \\
\hline Firm fixed effects & $\mathrm{Y}$ & $\mathrm{Y}$ & $\mathrm{Y}$ & $\mathrm{Y}$ \\
\hline Year fixed effects & Y & Y & Y & Y \\
\hline FDI determinants $\times$ Year dummies & $\mathrm{Y}$ & Y & $\mathrm{Y}$ & $\mathrm{Y}$ \\
\hline Tariff reductions $\times$ Year dummies & Y & $\mathrm{Y}$ & $\mathrm{Y}$ & $\mathrm{Y}$ \\
\hline SOE privatization $\times$ Year dummies & $\mathrm{Y}$ & Y & Y & Y \\
\hline Time-varying firm controls & $\mathrm{Y}$ & $\mathrm{Y}$ & $\mathrm{Y}$ & $\mathrm{Y}$ \\
\hline Observations & $1,368,957$ & $1,368,957$ & $1,347,189$ & $1,119,151$ \\
\hline
\end{tabular}

Note: Determinants of changes in FDI regulations include new product intensity, export intensity, number of firms, and average age of firms at the 4-digit industry level in 1998. Tariff reductions include output tariff, input tariff, and export tariff at the 4-digit industry level in 2001. SOE privatization is a ratio of state-owned enterprises in the total number of firms at the 4-digit industry level in 2001. Time-varying firm controls include firm output, export status, capital-labor ratio, and SOE dummy. Bootstrapped standard errors are clustered at the 4-digit industry level in parenthese. $* * *, * *$ and $*$ denote significance at the 1,5 and $10 \%$ level respectively. 
Table 5: Absorptive capacity

\begin{tabular}{lcc}
\hline \hline Dependent variable: $(\log )$ firm TFP & R\&D intensity & SOE \\
\hline FDI sector & $(1)$ & $(2)$ \\
\hline FDI sector $\times$ R\&D intensity in 2001 & $0.1485^{* * *}$ & $-3.376^{* * *}$ \\
& $(2.140)$ & $(0.101)$ \\
FDI sector $\times$ SOEs dummy in 2001 & & \\
& & $0.361^{* *}$ \\
Firm fixed effects & $\mathrm{Y}$ & $(0.163)$ \\
Year fixed effects & $\mathrm{Y}$ & $\mathrm{Y}$ \\
& & $\mathrm{Y}$ \\
FDI determinants $\times$ Year dummies & $\mathrm{Y}$ & $\mathrm{Y}$ \\
Tariff reductions $\times$ Year dummies & $\mathrm{Y}$ & $\mathrm{Y}$ \\
SOE privatization $\times$ Year dummies & $\mathrm{Y}$ & $\mathrm{Y}$ \\
Time-varying firm controls & $\mathrm{Y}$ & $\mathrm{Y}$ \\
\hline Observations & 682,451 & 657,982 \\
\hline \hline
\end{tabular}

Note: Determinants of changes in FDI regulations include new product intensity, export intensity, number of firms, and average age of firms at the 4-digit industry level in 1998. Tariff reductions include output tariff, input tariff, and export tariff at the 4-digit industry level in 2001. SOE privatization is a ratio of state-owned enterprises in the total number of firms at the 4-digit industry level in 2001. Time-varying firm controls include firm output, export status, capital-labor ratio, and SOE dummy. Bootstrapped standard errors are clustered at the 4-digit industry level in parenthese. ${ }^{* * *}, * *$ and $*$ denote significance at the 1,5 and $10 \%$ level respectively. 
Table 6: Other measures of firm performance

\begin{tabular}{lccccc}
\hline \hline Dependent variable & Export status & Export intensity & $(\log )$ wage rate & $\begin{array}{c}\text { New product } \\
\text { intensity }\end{array}$ & Exit \\
\hline FDI sector & $(1)$ & $(2)$ & $(3)$ & $(4)$ & $(5)$ \\
& 0.069 & 0.055 & $1.125^{* * *}$ & 0.053 & $-0.260^{* *}$ \\
& $(0.080)$ & $(0.042)$ & $(0.193)$ & $(0.033)$ & $(0.103)$ \\
Firm fixed effects & & & & & \\
Year fixed effects & $\mathrm{Y}$ & $\mathrm{Y}$ & $\mathrm{Y}$ & $\mathrm{Y}$ & $\mathrm{Y}$ \\
& & $\mathrm{Y}$ & $\mathrm{Y}$ & $\mathrm{Y}$ & $\mathrm{Y}$ \\
FDI determinants $\times$ Year dummies & $\mathrm{Y}$ & $\mathrm{Y}$ & $\mathrm{Y}$ & $\mathrm{Y}$ & $\mathrm{Y}$ \\
Tariff reductions $\times$ Year dummies & $\mathrm{Y}$ & $\mathrm{Y}$ & $\mathrm{Y}$ & $\mathrm{Y}$ & $\mathrm{Y}$ \\
SOE privatization $\times$ Year dummies & $\mathrm{Y}$ & $\mathrm{Y}$ & $\mathrm{Y}$ & $\mathrm{Y}$ & $\mathrm{Y}$ \\
Time-varying firm controls & $\mathrm{Y}$ & $\mathrm{Y}$ & $\mathrm{Y}$ & $\mathrm{Y}$ & $\mathrm{Y}$ \\
\hline Observations & $1,368,957$ & $1,368,957$ & $1,365,869$ & $1,197,222$ & $1,368,957$ \\
\hline \hline
\end{tabular}

Note: Determinants of changes in FDI regulations include new product intensity, export intensity, number of firms, and average age of firms at the 4-digit industry level in 1998. Tariff reductions include output tariff, input tariff, and export tariff at the 4-digit industry level in 2001. SOE privatization is a ratio of state-owned enterprises in the total number of firms at the 4-digit industry level in 2001. In columns 1-2, time-varying firm controls include firm output, capital-labor ratio, and SOEs dummy. In columns 3-5, time-varying firm controls include firm output, export status, capital-labor ratio, and SOE dummy. Bootstrapped standard errors are clustered at the 4-digit industry level in parenthese. ***, ** and $*$ denote significance at the 1,5 and $10 \%$ level respectively. 
Table A1: Changes of FDI regulations (product level) between 1997 and 2002

\begin{tabular}{|c|c|c|c|c|c|c|}
\hline & & & \multicolumn{4}{|c|}{2002} \\
\hline & & & (1) & (2) & (3) & (4) \\
\hline & & & $\begin{array}{c}\text { Supported } \\
\text { Category }\end{array}$ & $\begin{array}{c}\text { Permitted } \\
\text { Category }\end{array}$ & $\begin{array}{c}\text { Restricted } \\
\text { Category }\end{array}$ & $\begin{array}{c}\text { Prohibited } \\
\text { Category }\end{array}$ \\
\hline \multirow{4}{*}{1997} & & $\begin{array}{l}\text { Supported } \\
\text { Category }\end{array}$ & No-change & Less welcome & Less welcome & Less welcome \\
\hline & (2) & $\begin{array}{l}\text { Permitted } \\
\text { Category }\end{array}$ & More welcome & No-change & Less welcome & Less welcome \\
\hline & & $\begin{array}{l}\text { Restricted } \\
\text { Category }\end{array}$ & More welcome & More welcome & No-Change & Less welcome \\
\hline & & $\begin{array}{l}\text { Prohibited } \\
\text { Category }\end{array}$ & More welcome & More welcome & More welcome & No-Change \\
\hline
\end{tabular}


Table A2: Determinants of changes in FDI regulations (industry level)

\begin{tabular}{lcc}
\hline \hline Dependent variable: Changes in FDI regulations & $(1)$ & $(2)$ \\
\hline New product intensity & $1.571^{* * *}$ & $1.558^{* * *}$ \\
Export intensity & $(0.253)$ & $(0.260)$ \\
& $-0.257^{* *}$ & $-0.255^{* *}$ \\
(log) number of firms & $(0.106)$ & $(0.106)$ \\
& $0.032^{*}$ & $0.032^{*}$ \\
Ellison-Glaeser index & $(0.016)$ & $(0.016)$ \\
& 0.742 & 0.732 \\
Average age of firms & $(0.566)$ & $(0.570)$ \\
& $-0.009^{* *}$ & $-0.009^{* *}$ \\
(log) average employment & $(0.004)$ & $(0.004)$ \\
& -0.009 & -0.008 \\
(log) average wage per worker & $(0.036)$ & $(0.036)$ \\
& 0.086 & 0.087 \\
(log) TFP & $(0.078)$ & $(0.078)$ \\
& & 0.010 \\
Observations & & $(0.051)$ \\
\hline \hline
\end{tabular}

Note: Observations are at the 4-digit industry level. Robust standard errors are in parenthese. $* * * * *$ and $*$ denote significance at the 1,5 and $10 \%$ level respectively. 